\title{
Feasibility and Sustainability Challenges of the Süleyman's Türbe Cultural-Tourism Centre Project in Szigetvár, Hungary
}

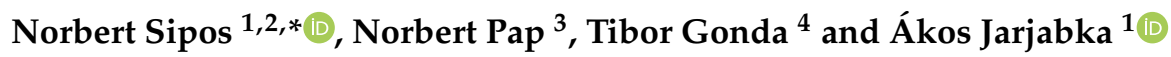 \\ 1 Department of Leadership and Organisational Sciences, Faculty of Business and Economics, \\ University of Pécs, Rákóczi Str. 80, H-7622 Pécs, Hungary; jarjabka.akos@ktk.pte.hu \\ 2 Comparative and European Research Group on Employment Policy and Labour Law, 48-as Sqr. 1, \\ H-7622 Pécs, Hungary \\ 3 Department of Political Geography, Development and Regional Sciences, Faculty of Sciences, \\ University of Pécs, Ifjúság Str. 6, H-7624 Pécs, Hungary; pnorbert@gamma.ttk.pte.hu \\ 4 Department of Marketing and Tourism, Faculty of Business and Economics, University of Pécs, \\ Rákóczi Str. 80, H-7622 Pécs, Hungary; gonda.tibor@ktk.pte.hu \\ * Correspondence: sipos.norbert@ktk.pte.hu
}

check for updates

Citation: Sipos, N.; Pap, N.; Gonda, T.; Jarjabka, Á. Feasibility and Sustainability Challenges of the Süleyman's Türbe Cultural-Tourism Centre Project in Szigetvár, Hungary. Sustainability 2021, 13, 5337. https:// doi.org/10.3390/su13105337

Academic Editors: Lóránt

Dénes Dávid, Peter Szende and Martin Balázs Zsarnóczky

Received: 2 April 2021

Accepted: 6 May 2021

Published: 11 May 2021

Publisher's Note: MDPI stays neutral with regard to jurisdictional claims in published maps and institutional affiliations.

Copyright: (c) 2021 by the authors. Licensee MDPI, Basel, Switzerland. This article is an open access article distributed under the terms and conditions of the Creative Commons Attribution (CC BY) license (https:/ / creativecommons.org/licenses/by/ $4.0 /)$.

\begin{abstract}
The Süleyman's Türbe in Szigetvár (Hungary) is a historical monument with exceptional features; the aim of the study is to present the planned cultural-tourism centre investment goals, risks and externalities. Cultural and tourism specificities significantly influence the implementation of such unique, three nations concerning projects. One of the crucial conditions of the implementation is the integration into the existing cultural heritage plans and the proper management of the related uncertainties. The authors decided to handle the Türbe as an investment project; therefore, a tourism exploratory analysis, a risk analysis, and externalities identification are discussed in this paper. The project development was carried by nominal groups between June and December of 2019 using professional experts workshops, group decision and information gathering approaches. The paper is using a case-study-based investigation. The most significant risks and their mitigation strategies are the emergences of Turkish influence: Turkish-Hungarian consultation, intensive consultation with Turkish Cooperation and Coordination Agency (TCCA); problems related to expropriation: preventive communication, cultivating good relations; delay in project implementation: professional lobby, preparation of scenarios. This study aims to present the design model of this multifaceted, international-scale project. It is suggested that similar projects should be handled and considered as a whole to reach the maximum of their potential.
\end{abstract}

Keywords: cultural tourism; heritage tourism; Süleyman's Türbe; risk management

\section{Introduction}

There are a number of factors to consider when planning and managing mega-projects in a regional sense and projects in support of cultural heritage. Stendebakken and Olsson [1] highlight the need to preserve the values that are part of the cultural heritage to allow future generations to learn from them. During the preparation of cultural investment, increased attention should be paid not only to the preservation of authenticity but also to the issue of identity [2]. Finding the ruins of Süleyman's Türbe in Szigetvár was a world sensation in itself [3,4]; however, the permanent presentation of the discovered remains to a broad audience, in the place of the memorial site seems to be a serious challenge, taking into account the principle of sustainability, too. Partal and Dunphy [5] emphasise that projects that do not deal with planning cultural elements mostly fail. Generally, this element usually occurs after the most important financing and subsidisation decisions have already been made. De Medici et al. [6] describe in their study what role the preservation and reuse of existing cultural relics play in the life of city inhabitants. As a significant part of the population lives in towns, projects with such a role should consider efficiency and utility 
elements as they contribute to knowledge transfer spanning generations. This is especially important for projects that are associated with outstanding historical events or people. In these cases, great emphasis must also be placed on the educational impact of tourism [7]. All these contribute to a sustainable economy that does not necessarily appear directly as profit but indirectly as stimuli within a region. Nocca [8] found that cultural heritage and sustainability can provide long-lasting economic advantage to a certain region in the case of adequately managed projects. For Szigetvár and its surroundings (it is situated in Transdanubia, close to the Croatian border), the Süleyman's Türbe to be built on the site as a tourism-related investment, is an economic development opportunity which should be exploited. This makes the question a current and important topic beyond the international archaeological performance.

The battle of Szigetvár and the death of Süleyman in 1566 symbolically resulted in halting the European expansion of the Ottoman Empire and protecting Christianity. Therefore, a worthy memorial place can highlight its historical importance for both cultures.

In addition to the local appearance of cultural values, the link between cultural values, local appearance and the income generated by sustainable tourism has been proved for a long time [9]. This is enabled by a realistic and prudent scenario analysis during project planning, which also helps to integrate stakeholder expectations.

There is a number of intercorrelated elements in project management, which should be considered during the implementation of similar investments or their feasibility studies [10]. Bringing together two different disciplines (the economic-orientated project management and the less operationalisable cultural-tourism) has its definitive challenges with which project management practitioners, academia and decision-makers struggle.

It is a rarity to find a similar sacred legacy of such a world-famous historical figure as Süleyman. Perhaps the exploratory work that has been successfully realised with 21stcentury 3D landscape reconstruction techniques based on historical descriptions can be compared to the discovery of the ruins of Troy by Henrik Schliemann. There are therefore very few benchmarks that could serve as a basis for creating such a Centre. The picture is further complicated by the fact that Süleyman was considered the "ancient enemy" of the medieval Hungarian Kingdom, and his heroic cult of Miklós Zrínyi (who was born in the territory of Croatia), who opposed him in Szigetvár and died heroically doing it. These powerful counterforces should appear and be respected simultaneously in a similar project. Based on this, the authors' research question can be formulated as follows: How can this historical opposition be used to create a sustainable, business-based cultural-tourist attraction and institution of continuous domestic and international interest? How can it be ensured that the intellectual needs [11] of travellers are satisfied by a similar attraction? What are the factors which influence the political aspects of the heritage and still preserve the authenticity?

The study is structured in five chapters. Relying on the study of Pap et al. [12], the present paper focuses on the project-related planning and feasibility elements of the Süleyman's Türbe Cultural-Tourism Centre in Szigetvár (hereinafter referred to as the Cultural-Tourism Centre, Süleyman's Türbe or Türbe Project). Besides, among the classic aspects of project management, risk management, possible externalities, and effects will be discussed [10]. The research is based on the analysis of the Türbe Project mainly relying on professional expert groups and multiperspective methods.

\section{The Türbe Project-Related Goals}

This chapter focuses on the framework of the project, giving an overview of the most important characteristics.

\subsection{The Vision of the Türbe Project}

The strategic aim of the planned Cultural-Tourism Centre is to obtain a complex, local community level benefit and added value of the investment on tourism, culture, society, and economy. In this way it can become a strong bastion of cultural tourism in Baranya 
County, attracting 100,000 to 200,000 Hungarian and international visitors, operating in a self-sustaining way in the future, creating jobs in the area and generating economic prosperity. The project's uniqueness and challenge lie in the fact that the archaeological discovery is not tied to the local heroes but to Süleyman, who appears as a conqueror in the area. Therefore, in the realisation of the memorial site and the communication of the project, the historical reconciliation and the heroism of the defenders must be displayed when emphasising the historical significance of Süleyman. The other challenge is to apply such a touristic interpretation approach that at the same time meets the modern consumer expectations and does not harm the authenticity of the site or damage the international recognition of the archaeological discovery [13]. The problem of reconciling interpretation and authenticity is a common issue in heritage tourism attractions [14]. Due to low population density and relatively untouched nature in rural areas, it is particularly important to study environmental and economic sustainability [15] during the planning phase.

\subsection{The Rationale and Timeliness of the Türbe Project}

The project is justified by the fact, that Süleyman, a significant figure of Middle Age world history, was buried temporarily (for 42 days) in Szigetvár. The town is involved in the cultural tourism of Baranya County, which is a central area of cultural tourism in Hungary. As for cultural-historical tourism, the Cultural-Tourism Centre could be a fundamental attraction. As for cultural-historical tourism, the Cultural-Tourism Centre could be a fundamental attraction. As the Ottoman-Turkish memories appear in the frame of the Zrínyi heritage, the realisation of the Centre is an aim of national politics. In the field of cultural-historical tourism, the Cultural-Tourism Centre would be a fundamental attraction factor. As the Ottoman-Turkish memorial world appears through the perspective of the Zrínyi heritage $[3,16]$, its realisation may become a Hungarian national policy goal as well. The Türbe Project should demonstrate the reconciliation over historical periods and religions by emphasising the heroism of Zrínyi and his soldiers to result in mutual honour and future cooperation [4]. The Government Decision 1427/2017. (VI. 29.) about the excavation in the vineyards of Szigetvár-Turbék and the expropriation of relevant properties [17] (p. 10267) indicates that the Government of Hungary recognises the outstanding significance of the cultural heritage values identified in the Vineyard of Szigetvár-Turbék, and considers it necessary to explore, get to know and protect them as fully as possible. This governmental intention and the dynamically growing demand for heritage tourism means the timeliness of the Türbe Project.

\subsection{The Concrete Objectives of the Türbe Project}

1. Constructing an open-air museum centre and a footpath for visitors to show finds and excavations in the venue.

2. Constructing a visitor centre, an appropriate building for informing the public about the history of the Süleyman's Türbe, parking places and infrastructure serving the visitors' needs, for commercial purposes (shops, restaurant) and scientific research and educational goals (exhibition and conference rooms, experience pedagogy methodology).

3. Creating a thematic historical circuit including the venue of excavations and further Ottoman buildings in the Castle of Szigetvár and its surroundings, connecting it to the other tourist attractions of Baranya County.

During the planning of the Cultural-Tourism Centre investment, a module-system consisting of three main elements was created, which are the following:

1. Central investment which enables the presentation and visiting of the Cultural Tourism Centre. It includes the use of the existing infrastructure.

2. Additional investment, which includes the proposal of the Municipality of Szigetvár to construct a Visitor Centre in the neighbourhood of the Cultural-Tourism Centre with additional parking places and a visitor path linking them with the CulturalTourism Centre. 
3. Background investments, which are necessary to create a complex tourism product, include a Memory Tour linking the historical monuments in Szigetvár and its surroundings with the Visitor Centre and the Cultural-Tourism Centre. In light of the study based on the return calculation models considering only the primary benefits, the recommended timing variant for decision-makers is the single-phase completion of the Cultural-Tourism Centre.

\subsection{The Methodological Approach of the Analysis}

The authors think that an appropriate methodological toolkit for making such poorly structured problems [18] well-designed is offered by the project management toolkit. This provides time and financial frameworks for the task, as well as the possibility to develop a preliminary analysis of medium- and long-term planning scenarios with assessing the risk of the project and estimating its sustainability parameters properly. The planning framework of the Türbe Project meets the criteria of the scientific definition of the projects [10], such as complexity, innovation content, strategic significance. Therefore, it was considered adequate to choose the project methodology tools.

The transformation of currently available archaeological results into a cultural heritage tourism product is a very complex, interdisciplinary task with many contextual approaches (such as archaeological, geographical, regional, historical, cultural, religious, tourist, architectural and regional economic development). The exploratory research took place between June and December of 2019 (with the participation of researchers of the University of Pécs, Hungary Academy of Sciences, experts of cultural projects, Turkish Cooperation and Coordination Agency, and other local non-profit and for-profit stakeholders), and the detailed results were summarised in a researcher report to the decision-makers [19].

The interdisciplinary research team [12], which analysed the problem, covered the relevant disciplines. During the work, they applied group decision and information gathering methodological elements such as two interdisciplinary workshops, group decision-making techniques (brainstorming, nominal group techniques), and assessment by multiple stakeholders [20].

Even if cultural-tourism investments are not rare as they used to be in the past [21], no similar project was identified during the feasibility study-writing phase. Therefore, in the absence of relevant benchmarks, the authors decided to present the scientific work on a case study basis, a qualitative approach as no quantitative analysis was possible [22,23].

\section{Cultural-Tourism Characteristics Supporting the Need for the Project}

Cultural tourism is the most dynamically developing sector of tourism in the world, which pace was accelerated in the 1990s [24]. This was when heritage tourism within cultural tourism became stronger and a separate form of tourism [25]. In 2015, 40\% of international travel was cultural in nature, which in 2017 already meant about 516 million trips [26]. Europe is still the world's leading cultural destination, where this growth was also experienced, although its market share in the global tourism market is declining [27]. Of UNWTO member states, $89 \%$ have identified cultural tourism as a critical element of their tourism policy [26]. Cultural and heritage tourism is a product of the tourism market that emphasises cultural and heritage attractions [28] and can satisfy the intellectual interest of travellers in the broadest sense [11]. Cultural tourism includes elements of cultural heritage (both built and intangible), manifestations of contemporary arts, cultural events, the utilisation of church sites, cultural trips and city visits, event tourism, youth tourism, etc. [29]. Culture has become a key tourist value, making differences between destinations with individual characteristics [30]. The development of cultural tourism became an innovative and creative method, forming a bridge to social, economic and human development [31]. The convergence of culture and tourism is influenced by a number of factors. The dynamic expansion of the demand side can be clearly felt, the reasons for which can be summarised as follows [32,33]: 
- a growing interest in culture, especially as a source of local identity in the face of globalisation,

- increase in the number of cultural trips,

- a higher level of education, higher free disposable income,

- the increasing use of new media and technology in information gathering and bookings,

- postmodern consumer patterns and the spread of the experience economy,

- as tourism grows, cultural sites and experiences become more accessible.

From the point of view of the Türbe Project, heritage tourism deserves particular emphasis, which is favoured by the appreciation of intellectual culture and heritage in the value system of the consumer side [34]. Heritage tourism is one of the most dynamically developing types of tourism products worldwide at the end of the 20th century [35]. At the beginning of the 21st century, they represent permanence in our changing and unifying world, so they are increasingly attractive in all areas of life [36]. Hargrove [37] called heritage tourism the fastest growing niche market. It has also the advantage of reducing the seasonality of tourism [38]. As a result, the harmful phenomenon of overtourism can already be observed in the most popular historical cities and heritage sites [39]. Silberberg [40] defines cultural and heritage tourism as a means of economic development by attracting visitors who are interested in the historical, artistic, scientific, or lifestyle heritage of the local community. This is why it often appears in underdeveloped areas as a tool for development [41]. Heritage can be targeted even by destinations that cannot position themselves with the attractions of $4 S$ (Scope, Site, Synergy, System) [42]. Interest in cultural tourism, including heritage tourism shows a dynamic growth also in Central and Eastern Europe $[23,43]$. Touristic consumer trend studies have drawn attention to the fact that travellers' intellectual interest is constantly growing in Hungary. As a consequence, the popularity of heritage tourism is constantly growing, too [44]. Heritage tourism is based on heritage, where heritage is both a central element of the product and the main motivation for tourists [45]. The goal of heritage tourism is to visit sites and participate in activities that authentically represent the events of the past and present, people who lived in the past and today [46]. A well-put-together heritage tourism product package can include historical, cultural and natural attractions.

In terms of the development of heritage tourism, monumental buildings, castles, chateaux, etc., to a different extent, but all have a positive economic impact on tourism as there is an opportunity to explore archaeological finds, conserve and reuse monuments [47]. In addition, the importance of heritage tourism in education should not be underestimated [48]. The built attractions of cities and towns (like Szigetvár) carrying the past's complex heritage also provide a background for the tourists' activities and experiences. That is why, in the case of a touristic visitor centre, which requires a significant investment, two issues need to be given special attention, among other things. On the one hand, the investment must be planned and realised by involving the whole region and with an integrative approach [49]; on the other hand, the destination management organisations operating in the given area must be involved as a partner in the development of project ideas.

Examining the current tourism practice of Szigetvár, it can be stated that it has connection points to all the listed product types of cultural tourism and has the initial potential necessary for their development. The establishment of the Cultural-Tourism Centre can be integrated into the framework of heritage tourism. With its implementation, one of the most important heritage tourism destinations in Hungary can be created. The planned investments of this project should be defined in such a way as to develop complex regional cultural tourism and to have a significant impact on all the listed branches of tourism. The majority of cultural trips are based on three attractions: the built heritage of cities, iconic facilities, and prestigious cultural events. The project deals with the development of all three attractions. Essentially, the Cultural-Tourism Centre creates an internationally visible iconic object, which could become a site for a historical reconciliation, where one can rise above the historical strife of centuries before. The Szigetvár Historical Route project 
element focuses on the built heritage of the town; the resources dedicated to covering the operating costs provide opportunities for organising prestigious cultural events and festivals, which, if they are linked to tourist attractions, can also result in bigger synergies.

In a representative survey of 2018 [50] (Figure 1), the habits and attitudes of the Hungarian population towards tourism were examined. Among other things, the research covered the types of attractions that tourists visit during their vacations/trips. As expected, respondents favour natural attractions and culture over shopping and leisure parks. The vast majority of respondents often visit natural attractions ( $74.4 \%$ in total), but the most popular are the cultural ones. It can be stated that visiting cultural attractions is one of the primary motivations for the decisive part of the Hungarian population for their trips, and it is certainly the most popular activity during their travel practice. This is confirmed by the results of the representative research, according to which $34 \%$ very often and a further $46.6 \%$ often incorporate cultural attractions into their travel program ( $80.6 \%$ in total).

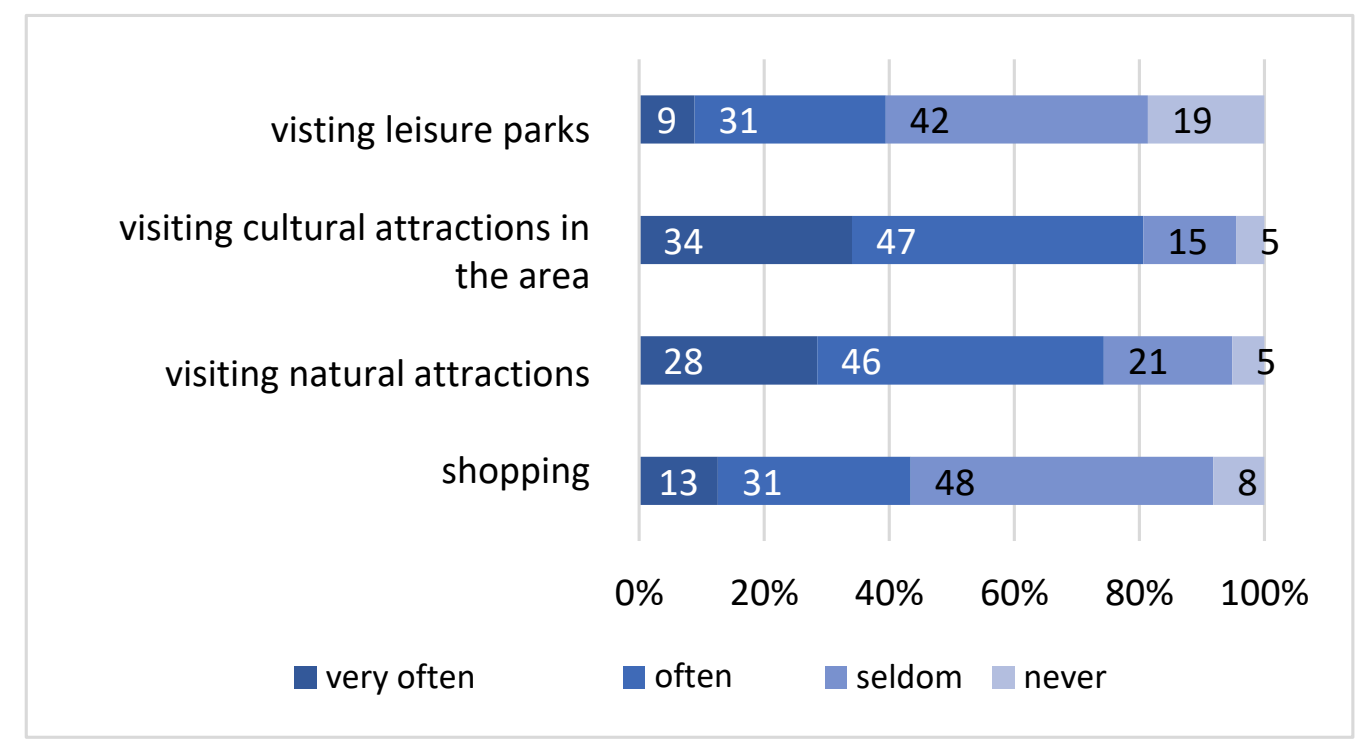

Figure 1. Distribution of domestic tourism habits; ref. [50]: 38.

Despite its many favourable features, visibility of tourist attractions of Baranya County in Hungary can be evaluated as medium, and it is primarily centred in Pécs. This means a moderate awareness in Hungary in the field of competition of large national regions and cities, but this is nonetheless true at the level of international tourism as well, where the attractiveness of Budapest (Hungarian Capital) prevails. At present, Mohács, Szigetvár and Siklós are known for their historical role, but they can be visited in a few hours as "transit" tourist destinations, which cannot contribute to the development of the region and to sustaining its economy. The communication of the above three settlements is also separated from each other; there is no substantial cooperation between them, and thus no synergy occurs.

The Türbe Project intends to implement precisely this complex cultural-tourism cooperation in the region, thus creating a mutually reinforcing, attractive package of services for tourists and a heritage tourism thematic route. Thematic roads connect natural or man-made attractions based on a specific theme, and these attractions can be accessed using some form of transport [51]. Routes can be product or theme-based [52-54]. The term "tourist route" means a variety of activities and attractions along a certain theme, thus encouraging businesses to provide complementary products and services $[55,56]$. Thus, route-based tourism is actually a market-driven approach to the development of tourist destinations [54]. The concept of their design is that the combination of activities and attractions in less developed areas generates cooperation and partnership between communities and neighbouring areas, thus contributing to economic development through tourism [57]. 
In developing a successful thematic route, the concept of partnership suggests that a competitive advantage can be gained through local clusters [58,59]. Cultural routes are a new way of preserving and exploiting heritage. They mean both a geographical journey as we go through different areas, local units, as well as a mental journey with values, feelings, emotions, experiences, which then come together into the final product. The concept of cultural routes means both a tourism product and a special methodology [60]; they are outstandingly innovative in the field of cultural heritage protection [51]. According to Fladmark [61], cultural heritage tourism not only means identifying, managing, and protecting heritage but also helps to understand the impact of tourism on local communities and regions, increase economic and social benefits, and generate the financial resources needed for protection, marketing, and promotion. The presented project concept was prepared, keeping in mind that the foundation of long-term sustainability is of utter importance in the case of cultural tourism projects [62]. The values of sustainable tourism must be enforced [63], and although the goal is to generate a significant number of visitors, the characteristics of alternative tourism must be given priority over mass tourism [64].

\section{Risk Analysis}

It is essential to identify the risks of the Cultural-Tourism Centre's project with negative returns arising from the uncertainty and name the related elimination, mitigation, and management methods [10]. With regard to the grouping of risks, those related to the investment and the operations can be logically separated. As a result of an expert workshop realised at the beginning of the planning phase, in addition to the identification of possible risk factors, with the use of the probability-impact matrix technique [65] for classifying the individual risk elements, low, medium, and high-risk categories were created [66]. It is recommended to use a different risk mitigation strategy for all of them. In total, three major risk groups can be distinguished, such as:

- Risks that require immediate intervention and cause a project crisis (in dark grey): Based on the probability of occurrence of the risk and the estimation of its impact, the high-high and medium-high, high-medium elements are those that pose a significant risk and need to be prioritised and monitored. If any of these situations occur, it questions the implementation and the feasibility of the Cultural-Tourism Centre project.

- Manageable risks that require regular monitoring (in medium-dark grey): Mediummedium and high-low, low-high-risk elements can influence the implementation and operation of the Türbe Project, but appropriate mitigation approaches can ensure their handling in such a way that they do not require further intervention even in their eventual occurrence.

- Risks that do not require the elaboration of an intervention mechanism (in white): These are the elements that can be classified as low-low or medium-low, low-medium risks. Their occurrence requires at most a loose follow-up. Basically, they are either elements (externalities) that cannot be influenced by the project, or their occurrence can be considered as part of the project within acceptable risk-bearing limits.

\subsection{Risks Arising during the Investment Phase of the Cultural-Tourism Centre}

This section will focus on the risks related to the construction phase, their management and mitigation strategies (Table 1). 
Table 1. The investment-related probability-impact matrix of Süleyman's Türbe Cultural-Tourism Centre Project in Szigetvár. Own edition based on [67] (p. 237) and [65] (p. 201).

\begin{tabular}{|c|c|c|c|c|}
\hline \multirow{6}{*}{ Probability } & \multicolumn{4}{|c|}{ Investment } \\
\hline & High & $\begin{array}{l}\text { Technology, } \\
\text { environment, weather, } \\
\text { wildlife }\end{array}$ & $\begin{array}{l}\text { Under-planning of } \\
\text { costs and lack of } \\
\text { resources in a } \\
\text { price-increasing } \\
\text { environment }\end{array}$ & $\begin{array}{l}\text { Emergence of Turkish } \\
\text { influence } \\
\text { Expropriation } \\
\text { Delay in project } \\
\text { implementation } \\
\text { Decline in tourist trips } \\
\text { related to the Covid } \\
\text { situation }\end{array}$ \\
\hline & Medium & & $\begin{array}{l}\text { Changes in the } \\
\text { composition of a } \\
\text { professional project } \\
\text { team } \\
\text { Social resistance or } \\
\text { Cultural rejection }\end{array}$ & $\begin{array}{c}\text { Uncertainty in } \\
\text { excavation works, e.g., } \\
\text { basement collapse }\end{array}$ \\
\hline & Low & Change of political will & & $\begin{array}{l}\text { Rejection of the } \\
\text { Cultural-Tourism } \\
\text { Centre investment by } \\
\text { the Hungarian } \\
\text { Government }\end{array}$ \\
\hline & & Low & Medium & High \\
\hline & & & & \\
\hline
\end{tabular}
Table 1):

Risks that require immediate intervention and cause a project crisis (in dark grey in

- Emergence of Turkish influence:

In the design of some elements of the project, a stronger and more direct eventual emergence of intervention from the Turkish Government directly affects the feasibility. The difference between the Turkish and Hungarian approaches can be traced back to the different historical interpretations of the event (Turkish: culture, the spread of religion, Hungarian: conquest). The Hungarian Government's Eastern and Southern Opening programs are decisive for future directions and investments. Still, it is also important that the Türbe Project is aligned with current Hungarian expectations and historical interpretation.

Risk management: during project management, a continuous professional consultation is needed between the Turkish and Hungarian parties at both professional and political levels, with particular emphasis on cooperation with the Directorate of TCCA (Turkish Cooperation and Coordination Agency).

The Hungarian aspects of the project must be continuously emphasised; in addition to diplomatic communication, the press can be used to present the Hungarian interests. At the same time, the importance of Turkish memories must be maintained, and it is worth communicating to both the Hungarian and Turkish public about the relationship between the two historical figures and emphasising Zrínyi's Croatian origins to the Croatian ethnic groups in Hungary and also while cooperating with the neighbouring country.

- Expropriation:

The historical project's place is determined by the archaeological site, as it is not possible to install the related infrastructure or services at a significant distance from it. Suppose the expropriation of the areas is not properly solved in the short term. In that case, the physical realisation of the project, the excavation and the construction of the Cultural-Tourism Centre and the facilities serving it may be directly endangered.

Risk management: Open and direct, preventive communication activities should be carried out towards the approximately $80-100$ owners of properties, and a positive attitude should be strengthened in the establishment of relations. The processes should be nurtured accordingly, and all questions should be answered quickly and efficiently. 
However, individual negotiations with the owners should be conducted in confidence, with the strictest level of secrecy, to avoid the formation of a price cartel. However, of course, it is also necessary to ensure compliance with the legal requirements during the process. In the case of expropriation, it is fortunate that these are typically non-residential owners, so as a result of successful mitigation actions, it is unlikely that resistance will develop that would hinder the implementation of the project.

- Delay in project implementation:

The investment-related project elements discussed in the feasibility study are realistic and relevant in the case of an implementation in the foreseeable future (2-3 years). However, any longer-term delay requires a rethinking of the whole concept and a revision of all preparation-related processes. This can be attributed to the fact that both the professional content and the stakeholder relationship system, as well as the cost and technological obsolescence of the investment elements, make it impossible to implement the project according to the preliminary feasibility study. Nonetheless, it has to be highlighted that the Türbe Project can be considered a soft time constraint [10] project, and so the most important element is the commitment by the side of the Hungarian Government and not the costs.

Risk management: To minimise or eliminate the negative consequences of time delays that may occur during implementation, it is necessary to develop several alternatives with the use of the scenario technique. The effect of the occurrence of influencing factors on the plans must be included in the planning by the so-called rolling redesign technique and ensuring problem recognition as soon as possible with constant project control. During the time lag, openness and the necessary transparency must be ensured to maintain local people's confidence in the project. Perhaps an even more important situation is if a major delay occurs because, in the last six months of the investment, the operation phase-related communication will have to start, with which the facilities will attract visitors almost immediately after the opening ceremony. This also means that the communication necessary for operation can only be started when the opening takes place within a foreseeable time.

- Under-planning of costs and lack of resources in a price-increasing business environment:

Proper estimation of investment and operation (sustainability) is an essential issue. In the current Hungarian construction sector situation, the drastic increase in construction material and labour costs in the short term appears to be a factor of uncertainty. The more time it takes from the planning to the actual implementation phase, the greater the financial risk will become.

Risk management: The construction cost elements of the investment may vary greatly due to the time delay of implementation. Their management can be ensured with a relatively large reserve $(10 \%)$ in the relevant budget part of the project plan, as well as by extrapolating the rate of price increase for all eligible costs and by creating scenarios. As for sure, it cannot be eliminated totally.

- Uncertainty in excavation works, e.g., basement collapse:

Archaeological excavations can present many uncertainties, as it is not entirely possible to know what obstacles can be hidden under the surface. Environmental and archaeological risks in the conditions of excavation work, e.g., a cellar collapse that has already occurred, has a negative effect (e.g., personal injury on the site, loss of finds). Still, it can also have a positive effect on the results: this is exactly what happened in July 2019, discovering many more valuable finds.

Risk management: The full range of risks in undiscovered areas cannot be determined with absolute certainty. However, preliminary impact assessments, soil mechanics and static studies are required. In addition to providing long-term expansion opportunities for the project, they will also contribute to the development of scenarios for the present investment. To avoid environmental damage, it is necessary to physically protect the finds, e.g., with foil, covering back with earth for longer periods. From a communication point of 
view, it is extremely important to inform as many people as possible about the finds and their context before the development starts so that those living in the area and treasure hunters do not look for a chance of further exploration.

- Decline in tourist trips related to the Covid situation

Considering the classical risk management aspects, the Covid 19 should not have placed here, as it occurred as an unforeseen event, as a result, it was not possible to prepare for the situation with an appropriate mitigation strategy, and its impact cannot be managed on the basis of the present information.

Covid 19 is an unforeseen negative factor that drastically affects travels to tourist destinations [68,69]. During the first wave of the pandemic, the possibility of travelling between certain countries was essentially banned. Basically, following the cease of the epidemic situation (the date of which is still uncertain), it is questionable to what extent the rehabilitation of tourism will take place. Some authors envision a radical change and reform of tourism [70]. On the one hand, the uncertainties of recent months will not go away without a trace. On the other hand, the economic growth at maximum is projected to stagnate, with a drastic decline for some scenarios [71], which will reduce the financial resource spendable for extra services. In addition, the impact of Covid 19 can be considered significant in the short term, although it is difficult to judge at this stage how much influence it will actually have in the upcoming years. The authors are confident that the hopefully soon-to-be favourable turnaround will result a rapid boom and thus a sharp rise in the tourism industry.

Manageable risks that require regular monitoring (in medium dark grey in Table 1):

- Technology, environment, weather, wildlife:

The Cultural-Tourism Centre-related excavation and investment will both take place outdoors, i.e., it is indispensable that the schedule should be in accordance with the weather conditions necessary for the construction. External construction works can typically be carried out cost-effectively between April and October. At the same time, bad weather can endanger the finds, the protection of which and even the partial reconstruction of the Türbe require special expertise and construction technology.

Risk management: A thoroughly planned construction schedule should be prepared that takes into account the above seasonal periods and includes plans for internal work so that it can be implemented even in unfavourable weather. According to our current knowledge, none of the environmental aspects that may arise appears to be a source of an unbeatable obstacle, but they cannot be excluded either. The presentation of the environmental considerations of the project is an ongoing part of communication.

- Changes in the composition of a professional project team:

The experts involved in the preparation of the project, on the one hand, must have knowledge of project management and, on the other hand, have to cover all professional areas. In the present state, this is ensured; however, due to the relatively limited number of available professionals, the loss of one participant can result in a significant time delay and competence shortage. Another source of the problem is that the design and implementation team is expected to have a different composition. Then, from the very beginning, the replacement required due to the exchange of those who are familiar with the different elements of the process, as well as the time required to get updated with the actual situation, is more significant.

Risk management: Beyond gathering the necessary experts, it is expected that at least one replacement should be identified in the event of any non-availability due to external factors. It is natural that the possibly new entrants should be informed in an appropriate and timely manner. Activation of the expert pool system is possible at any time; it is important to monitor this. On the one hand, the substitution table, on the other hand, the contact matrix, but then again, the constant communication to the newly recruited experts makes the risk manageable, which should be done as long as possible through a 
formal handover activity. Project team communication is supported by cloud-based team management software.

- Social resistance or Cultural rejection:

In Hungary, the century and a half long Turkish occupation has left a historically significant, painful mark on various society segments. A commemoration project for such a period can stir up ideas that encourage activity and resistance from both local and national or even international stakeholders with significant leverage to prevent the investment from taking place. Additionally, the political processes taking place in Turkey and the political cooperation with the country may provoke considerable resentment either in Hungary or within the European Union.

However, the Cultural-Tourism Centre project is closely related to the protection of Miklós Zrínyi's heritage, so more serious resistance is unlikely, at least not in Szigetvár and its surroundings.

Risk management: Preventive communication, good relationship building, and ongoing management with all potential stakeholders with greater influence have a crucial role to play in managing the latent problem. There are several tools of communication management, which are described in the feasibility study, for example, public forums, radio interviews, expert opinions, presentation of the objectives of the investment on posters, advertisements, etc. In the content elements of communication, it should be emphasised that through the Turkish legacy, it wants to pay tribute to the Hungarian heroes, which clearly focuses on the past, while present processes do not appear. It is worth keeping the "Hungarian-Turkish" word order in communication.

- Rejection of the Cultural-Tourism Centre investment by the Hungarian Government:

The project expects to involve governmental resources, as no financial return in the medium term can be foreseen for both its implementation and operation. As a result, the positive, active contribution of the current Government is the key to the success of the investment. The Hungarian Government's policy of Eastern Opening is a clear commitment, but at the same time, of course, professional-based construction and transparent planning are needed to ensure the soundness of the project.

Risk Management: Active communication with the Hungarian Government and professional actors and extensive social discussion of the project. In addition to nurturing historical and national memory, communication also requires the presentation of the positive economic effects of development in the region.

Risks that do not require the elaboration of an intervention mechanism (in white in Table 1):

- $\quad$ Change of political will:

In principle, the change of Hungarian and Turkish political parties may make the implementation of the project impossible. However, this is unlikely, as opposing political groups in Turkey are also Hungarian-friendly, and Süleyman's heritage is important to all political forces.

Risk management: Preparing the implementation of the investment project as soon as possible, as project management has no influence on this factor.

\subsection{Risks Arising during the Operation Phase of the Cultural-Tourism Centre}

This section will focus on the risks related to the operation phase, their management and mitigation strategies (Table 2). 
Table 2. The operations-related probability-impact matrix of Süleyman's Türbe Cultural-Tourism Centre Project in Szigetvár. Own edition based on [67] (p. 237) and [65] (p. 201).

\begin{tabular}{cccc}
\hline \multirow{3}{*}{ Probability } & \multicolumn{3}{c}{ Operations } \\
\hline & Medium & $\begin{array}{c}\text { Technology, } \\
\text { environment, } \\
\text { weather }\end{array}$ & $\begin{array}{c}\text { Employment of } \\
\text { qualified human } \\
\text { resources }\end{array}$ \\
\cline { 2 - 4 } & Low & $\begin{array}{c}\text { Capacity and } \\
\text { infrastructure of } \\
\text { Szigetvár }\end{array}$ \\
\cline { 2 - 4 } & Low & $\begin{array}{c}\text { Financing of } \\
\text { operation }\end{array}$ \\
\hline
\end{tabular}

Risks that require immediate intervention and cause a project crisis (in dark grey in Table 2):

- Employment of qualified human resources:

After finalising the investment, a team of employees and managers with different knowledge and qualifications will be required to operate. In the case of jobs that do not require a qualification or only a lower level (cleaning, guarding and protection service, maintenance), the workforce can be recruited from the local area. At the same time, job positions with a higher level or specialised competence expectations, e.g., potential employees with Turkish and other foreign language skills, are unfortunately only partially available at present. On the one hand, there is a need for professional management with adequate knowledge to operate such a Cultural-Tourism Centre. On the other hand, there is currently no tour guide pool or people offering such services (guides, specialists for lectures).

Risk management: One of the possible solutions is the education and training of the necessary professionals and the provision of continuous internships through close cooperation with the University of Pécs. Following the implementation decision, it is advisable to start the cooperation, so that due to the passage of the training time, the necessary graduates will be available in the short term. However, it should also be considered that the University of Pécs should play a key role in the implementation of the development due to its geographical proximity and regional embeddedness. Another option is to attract a skilled workforce from another region, but it would be important for local stakeholders with interests in the realisation of the investment, not to involve external actors. It could be an added value for these groups to ensure that local employment is a realistic alternative for young people with higher education attainment levels.

An open communication strategy, maintaining local interest, and ongoing consultation with creative industry players will help engage the right professionals for the project.

- Capacity and infrastructure of Szigetvár:

Due to the estimated number of visitors, the increasing tourist traffic can no longer be served by the existing infrastructure (hotels, restaurants and companies providing quality services in the city). The lack of higher-class accommodation and the low number of beds, the overcrowding at the same time can prevent potential visitors from arriving in the city. In addition to the planned annual number of visitors, the current capacities are insufficient.

Risk management: Governmental financial support and calls for tenders in Szigetvár and its region in parallel with the construction of the Cultural-Tourism Centre are indispensable. Besides, it is necessary to review the urban development plan and approve it with the municipal body. The creation of high-quality accommodations for the tourists can be established within a reasonable timeframe if the tourism organisations, the municipal actors, and the inhabitants can cooperate closely.

Manageable risks that require regular monitoring (in medium-dark grey in Table 2): 
- Financing of operation:

In the case of the investment, self-sustainability can only be expected in the medium term; therefore, financing of the operation emerges as a significant risk factor. However, this factor may fall only into the medium-risk category because the governmental support for the implementation is evidenced. However, it is also essential to make plans, taking into account the principle of prudence, knowing the fact that budget support is a government decision to be made repeatedly every year.

Risk management: The aim is to reduce external exposure, i.e., to increase the appropriate level of own revenues and to minimise maintenance costs. Maximising own revenues is possible with a dynamic and responsive program calendar (selling tickets, creating various thematic exhibitions, hosting conferences) as well as actively monitoring other sources of revenue (European Union and Hungarian tender sources, grants). Minimising maintenance costs could be helped by the installation of renewable energy source-based devices during the construction phase

- Technology:

The technology element appears during both investment and operation, with the same medium level of risk. During operation, factors that could not be expected before may come to light. This requires additional funding and human resources, which determines the amount of long-term, permanent operating financial and human-resource support.

Risk management: Appropriate mitigation, a listing of alternative technological solutions, adapting technology to the operations.

- Environment, weather:

Due to its nature, the visiting of the Cultural-Tourism Centre is strongly exposed to the weather; the main visitor season is between April and October. However, unexpected weather anomalies around major Hungarian and Turkish dates may discourage those intending to travel.

Risk management: A well-planned program calendar should be created, which focuses on the possible intention to visit on important dates but also offers an alternative that can be realised indoors to avoid visitors' disappointment.

In addition, program management must take into account the specificities of different target groups in order to make the Cultural-Tourism Centre an attractive target even in less active periods (e.g., hosting school groups in winter for battle-related knowledge dissemination).

Overall, by identifying the risks, there is no factor that would jeopardise the implementation or operation of the investment to such an extent that the realisation of the Cultural-Tourism Centre investment cannot be recommended (Table 4), but the Hungarian Government's umbrella financial activity is a fundamental prerequisite.

Table 3. The high and medium risks and their mitigation and management strategies of the Süleyman's Türbe CulturalTourism Centre Project in Szigetvár. Own edition.

\begin{tabular}{|c|c|c|c|}
\hline Risk Levels & Investment & Operations & Mitigation, Management \\
\hline Medium & $\begin{array}{l}\text { Changes in the composition of } \\
\text { a professional project team }\end{array}$ & & $\begin{array}{l}\text { Creation of expert pool, } \\
\text { substitutions }\end{array}$ \\
\hline Medium & $\begin{array}{l}\text { Social resistance or } \\
\text { Cultural rejection }\end{array}$ & & $\begin{array}{l}\text { Preventive communication, } \\
\text { cultivating good relations, } \\
\text { public forums, expert articles }\end{array}$ \\
\hline Medium & $\begin{array}{l}\text { Rejection of the } \\
\text { Cultural-Tourism Centre } \\
\text { investment by the } \\
\text { Hungarian Government }\end{array}$ & & $\begin{array}{l}\text { Active communication, } \\
\text { creating scenarios }\end{array}$ \\
\hline Medium & Technology & & $\begin{array}{l}\text { Listing alternative } \\
\text { technological solutions, } \\
\text { adapting technology to the } \\
\text { implementation }\end{array}$ \\
\hline
\end{tabular}


Table 4. The high and medium risks and their mitigation and management strategies of the Süleyman's Türbe CulturalTourism Centre Project in Szigetvár. Own edition.

\begin{tabular}{|c|c|c|c|}
\hline Risk Levels & Investment & Operations & Mitigation, Management \\
\hline Medium & $\begin{array}{c}\text { Environment, } \\
\text { weather, wildlife }\end{array}$ & & Time scheduling scenarios \\
\hline Medium & & Financing of operation & $\begin{array}{l}\text { Relying on own revenues } \\
\text { (ticket, tender, grants) }\end{array}$ \\
\hline Medium & & Technology & $\begin{array}{l}\text { Listing alternative } \\
\text { technological solutions, } \\
\text { adapting technology to the } \\
\text { implementation }\end{array}$ \\
\hline Medium & & Environment, weather & Time scheduling scenarios \\
\hline High & $\begin{array}{l}\text { Emergence of Turkish } \\
\text { influence }\end{array}$ & & $\begin{array}{c}\text { Turkish-Hungarian } \\
\text { professional consultation } \\
\text { with TCCA }\end{array}$ \\
\hline High & Budget under-planning & & $\begin{array}{l}\text { Creating scenarios, } \\
\text { planning reserves }\end{array}$ \\
\hline High & $\begin{array}{l}\text { Excavation works, e.g., } \\
\text { basement collapse }\end{array}$ & & $\begin{array}{l}\text { Impact assessment, soil } \\
\text { mechanics and static testing }\end{array}$ \\
\hline High & Expropriation & & $\begin{array}{l}\text { Preventive communication, } \\
\text { cultivating good relationships }\end{array}$ \\
\hline High & $\begin{array}{l}\text { Delay in project } \\
\text { implementation }\end{array}$ & & $\begin{array}{l}\text { Professional lobby, } \\
\text { planning scenarios }\end{array}$ \\
\hline High & & $\begin{array}{l}\text { Employment of qualified } \\
\text { human resources }\end{array}$ & $\begin{array}{l}\text { Cooperation with the } \\
\text { University of Pécs, the } \\
\text { formation of necessary } \\
\text { specialists, provision of } \\
\text { professional practitioners }\end{array}$ \\
\hline High & & $\begin{array}{l}\text { Capacity and infrastructure } \\
\text { of Szigetvár }\end{array}$ & $\begin{array}{l}\text { The development of local } \\
\text { businesses and the } \\
\text { construction of high-quality } \\
\text { hotels and restaurants should } \\
\text { be a priority for the city }\end{array}$ \\
\hline
\end{tabular}

This section may be divided by subheadings. It should provide a concise and precise description of the experimental results, their interpretation, as well as the experimental conclusions that can be drawn.

\section{Externalities-The Analysis of Secondary Utility and Cost Factors}

In general, the payback cannot be directly calculated in the case of the realisation and operation of historical projects and complex tourism products such as the Türbe Project in Szigetvár. Therefore, it is not adequate to force an approach that is shortterm and exclusively profit-oriented. Consequently, beyond the primary cost and profit analysis, the long-term secondary benefits also should be considered both from social and environmental aspects $[10,66]$. Most of which cannot be easily monetised, but their positive effect is evident.

Considering all of the above, the potential factors of the primary and secondary benefits of the Cultural-Tourism Centre are described in the table (Table 5).

The primary benefits and costs contain positive impacts for those who are directly involved in the project and use the service. They can be planned clearly, and the realisation of the project ensures their occurrence.

The secondary, social benefits are not necessarily monetisable, although they affect the everyday life of people living in the closer and farther environment of the project. It also means that these indirect benefits do not involve the beneficiaries or users of the project directly, but exploiting its externalities [10]. 
Table 5. The primary and secondary benefits and costs of Süleyman's Türbe Cultural and Tourism Centre in Szigetvár. Own edition. The prices are calculated on 2021 HUF-EUR exchange ratios.

\begin{tabular}{|c|c|c|}
\hline & Benefits and Utility & Costs and Arising Problems \\
\hline $\begin{array}{l}\text { Primary factors (quantifiable and } \\
\text { measurable in the short term) }\end{array}$ & $\begin{array}{c}\text { Ticket sales calculated in medium-term } \\
\text { with } 150-200,000 \text { visitors and } \\
\text { 1.14-1.43 million EUR income yearly } \\
\text { Related benefits from souvenirs, } \\
\text { parking, etc. } \\
\text { Other benefits from letting out } \\
\text { establishments and sponsorship } \\
\text { Winning domestic and international } \\
\text { tenders with non-reimbursable grants } \\
\text { Increase of income from state and local } \\
\text { taxes due to the increase in guest nights } \\
\text { and visitor consumption }\end{array}$ & $\begin{array}{l}\text { Costs of Türbe investment (depending on } \\
\text { the rate of implementation, } \\
\text { 14.3-42.9 million EUR calculated with } \\
\text { present prices). } \\
\text { Further costs of archaeological } \\
\text { excavations and operational costs of the } \\
\text { Cultural-Tourism Centre } \\
\text { Decreasing state financing of the } \\
\text { operational costs, from annual } 2.3 \text { million } \\
\text { EUR in the beginning }\end{array}$ \\
\hline $\begin{array}{l}\text { Secondary factors (estimated, difficult to } \\
\text { quantify, having long term effects) }\end{array}$ & $\begin{array}{l}\text { Strengthening national identity and } \\
\text { preserving traditions } \\
\text { Appreciation of existing historical and } \\
\text { intangible heritage, strengthening of } \\
\text { local identity } \\
\text { Increasing the international visibility of } \\
\text { Hungary and Szigetvár, developing the } \\
\text { international image and twin } \\
\text { town relations } \\
\text { Improvement of institutional rankings } \\
\text { due to international scientific results } \\
\text { Strengthening international bilateral } \\
\text { political relations between Hungary } \\
\text { and Turkey } \\
\text { Creating workplaces in the region, } \\
\text { lowering the unemployment rate, } \\
\text { increasing the active employment rate } \\
\text { regionally, mainly in tourism and catering } \\
\text { More effective retention of local citizens } \\
\text { and labour force } \\
\text { Strengthening of the local economy and } \\
\text { increasing income } \\
\text { Increase in local real estate prices } \\
\text { Development of regional infrastructure } \\
\text { (roads, airport) } \\
\text { Improving vision for the future, the } \\
\text { region becomes more liveable, improving } \\
\text { the inhabitants' standard and quality } \\
\text { of life } \\
\text { Strengthening civil diplomacy, increase in } \\
\text { the level of social activity and stopping } \\
\text { the migration from the region } \\
\text { Spreading touristic buoyancy in touristic } \\
\text { centres of the region for example in } \\
\text { Harkány, Villány, Siklós, Mohács, } \\
\text { Pécs, etc. } \\
\text { Increasing the level of social tolerance }\end{array}$ & $\begin{array}{c}\text { Increase of the environmental impact of } \\
\text { the region as a consequence of interest } \\
\text { in tourism } \\
\text { Possible resistance of inhabitants because } \\
\text { of the Turkish features in their } \\
\text { built environment } \\
\text { Structural unemployment because of the } \\
\text { lack of professional knowledge and } \\
\text { command of foreign languages } \\
\text { Increasing dissatisfaction because of the } \\
\text { delay in construction works } \\
\text { Environment protection issues, which } \\
\text { might arise during construction works } \\
\text { Possible decrease in expected visitor } \\
\text { numbers in case of the interruption of } \\
\text { construction works }\end{array}$ \\
\hline
\end{tabular}

\section{Summary and Discussion}

Heritage tourism is the most dynamically developing branch of tourism, which is moving increasingly towards specialisation. Heritage tourists are looking for culture, history, archaeology, and last but not least, contact with the local population. The Türbe Project confirms the importance of preserving authenticity [2] and the possibility of reconciling the attractions of tourism and education [7]. However, it is unique in the sense that it is 
a historical event of great importance to three nations (Hungary, Croatia, Turkey) whose members look with respect to the concerning figures [4]. This is beneficial for the project from a marketing point of view, but it is also a unique challenge for the three nations involved to look at the historical figures and the event from a different perspective. Therefore, the intellectual content of the project must be determined by tactful consideration of different identities and commemoration policies [3], of course taking care of credibility and authenticity [37]. The findings are useful to understand the ways how to tackle the issues of the political nature of cultural heritage and tourism. The Türbe Project-related thoughts and experiences strengthen the possibility of satisfying the expectations of the business side but also incorporating the cultural heritage and local people perspectives, as stated by Timothy [9].

If the Türbe Project is implemented, it can meet all these expectations at a high level and in a complex way [1]. In addition to its other social and economic benefits, the implementation of the Cultural-Tourism Centre is also important for strengthening local communities and their identity [5]. Heritage tourism can also help to preserve the unique character of local communities and to support harmony and understanding between people. In addition, it helps preserve the natural and cultural treasures of nations while building awareness, creating new jobs, creating new business opportunities and thereby strengthening the local economy [6]. Every time a tourist visits a historic site, it helps preserve it and, through its economic impact, also contributes to improving the local population's and visitors' life quality [14].

Using the tools of project management related to the risk management $[10,68]$, the most important risk management issues of the Süleyman's Türbe Cultural and Tourism Centre in Szigetvár and the planned externalities and secondary effects can be identified in the study [72]. The assessment of risks is based on expert estimates but can be managed and mitigated appropriately by placing them in a $3 \times 3$ matrix. The most significant risks and their management are as follows:

- Emergence of Turkish influence: Turkish-Hungarian professional consultation with TCCA.

- Expropriation-related issues: Preventive communication, cultivating good relationships.

- Delay in project implementation: Professional lobby, planning scenarios.

This is in line with the findings and the suggested use of other authors [73-75] who found similar risks and mitigation strategies.

Throughout the project, the open, inclusive communication of the dual goal (heritage management and economic development) is characterised by the consideration of the peculiarities of national interest and Hungarian-Turkish cooperation, the emphasis on the secular nature and the transmission of proactive, strategically thought-out messages [76].

The authors of the study are convinced that the governmental decision will have a positive impact on all actors of the region, and in consequence, Baranya County could be enriched with a new historical commemorative place. Besides, for the complex assessment of the investment, it is practical to examine the analysis of the regional development plan in a separate study to investigate the synergistic effect of the development elements in proper depth. It is recommended to keep in mind that a holistic approach should be applied during the financial decision process, as a minimum value for minimum money will certainly not lead to the realisation of the positive primary and secondary benefits [8].

\subsection{Implications}

The study can bring an added value to both project management practitioners, academia, and decision-makers.

For the project management practitioners, it gives a benchmark on how to set up a similar team and which techniques should be applied to identify the potential conflict points and to create the necessary mitigation strategies. The multifold approach can ensure a close to zero planning bias, and by doing so, a higher level of acceptance by the side of the decision-makers can be achieved [73]. 
The benefits for academia are several. First, the appropriate synthetisation and synergies among the two disciplinaries can be used for other similar theoretical and empirical investigations. In this way, the very nature of similar investments can be understood better, which will reduce the related uncertainties [23].

Second, the cultural-tourism aspects of Dark Tourism [74] can also be extended by the findings of this paper. Even if the installation is based on the tragic death of several Hungarian and Turkish soldiers, the culture-related dissemination activities can be supported by showing the historical events. Additionally, the dissolution of the deeply rooted conflicts can be facilitated by giving place for commemoration. Furthermore, the tourism aspect and the direct and indirect impacts can ensure the economic development of the area, which can counterbalance the negative interpretations.

Third, the application of the project management tools can also generate a discussion about their appropriate use and added value in similar projects [72,77]. Overall, the project methodology form chosen for the study meets the criteria of cultural heritage tourism defined in the literature, but its uniqueness and, consequently, its maintenance risk is based on the fact that Süleyman Sultan can be defined as an ancient enemy. By the side of the governmental decision-makers, it has never been an easy task to decide whether a probably not fully self-sustainable (at least for the depreciation part) investment has to be realised or not, not considering the associated risk. This study, on the one hand, gives an overview of the investment and operations-related potential risks by giving a mitigation strategy, too. This aspect is crucial, as not only is the need for money the most fundamental question, but also the consideration of what burdens the project will have. If a strong stakeholder makes the implementation impossible, all of the related efforts are useless.

On the other hand, it is quite natural that the financial part should be clarified. The direct impact per sé is not sufficient to be analysed, as similar cultural projects are rarely self-financing [75]; therefore, this is not a valid expectation towards them. However, if a proper identification of the indirect effects can be listed and calculated, the rate of return can result in a positive outcome. In this way, the decision-making is supported by the long-term financial perspectives, too.

\subsection{Limitations and Further Research}

The paper focuses on the presentation of one case, one project; therefore, no quantitativesupported lessons can be drawn. In addition, only some parts of the project management tools are addressed. Therefore, as the successful planning and implementation depend on the intercorrelation of these elements, the mere findings cannot be used for other projects but only considering the other project management methods, too. A further limitation is that there are no similar projects which can be considered as a benchmark; therefore, this paper is more likely a theory-based investigation.

The authors, who also contributed to the creation of the preliminary impact study for Süleyman's Türbe, learned that in addition to the scientific excitement and goodwill, an objective and wide-ranging analysis is needed to ensure the development of the microregion in its final form. The next analytical phase should be part of a benchmark activity that compares the calculations with similar, already implemented projects, through which the cultural-tourism project-related peculiarities can be identified even more accurately. Furthermore, the above goals are to be adjusted based on the COVID-19 pandemic-related negative tourism effects that occurred after the finalisation of the preliminary impact study. It can be stated without doubt that this could be considered the biggest threat to launching the investment and achieving its long-term sustainability.

The central focus of further realisation alternatives could be the Mohács-Szigetvár axis as the National Memorial Place in Mohacs provides an excellent opportunity to link these historical scenes $[78,79]$. However, to investigate the effect on regional tourism and indirectly on economic development, we must separate the unique potential of different attractions and the factors of external economic prosperity and decline as well. Based on 
the above, a widespread analysis in a regional context can confirm the feasibility of the Turbék-centred project and the related governmental decision.

Author Contributions: Conceptualisation, N.S., N.P., T.G. and Á.J.; methodology, N.S., N.P., T.G. and Á.J.; validation, N.S., T.G. and Á.J.; formal analysis, N.S., T.G. and Á.J.; investigation, N.S., T.G. and Á.J.; resources, N.S., N.P., T.G. and Á.J.; writing—original draft preparation, N.S., N.P., T.G. and Á.J.; writing—review and editing, N.S., T.G. and Á.J.; visualisation, N.S.; supervision, N.P., T.G. and Á.J. All authors have read and agreed to the published version of the manuscript.

Funding: The publication was supported by the University of Pécs, Szentágothai Research Centre, Research Centre of Historical and Political Geography and PADME Foundation. The research was financed by the Higher Education Institutional Excellence Programme of the Ministry for Innovation and Technology in Hungary, within the framework of the 4th thematic programme "Enhancing the Role of Domestic Companies in the Reindustrialisation of Hungary" of the University of Pécs.

Institutional Review Board Statement: Not applicable.

Informed Consent Statement: Not applicable.

Data Availability Statement: The data presented in this study are available in a publication [12].

Conflicts of Interest: The authors declare no conflict of interest. The funder had no role in the design of the study; in the collection, analyses, or interpretation of data; in the writing of the manuscript; or in the decision to publish the results.

\section{References}

1. Stendebakken, M.O.G.; Olsson, N.O.E. Cultural heritage in project management: Project appraisal and quality assurance in the early phase of major public investments. Impact Assess 2017, 36, 131-144. [CrossRef]

2. Macdonald, S. A People's Story Heritage, Identity and Authenticity. In Touring Cultures: Transformations of Travel and Theory; Rojek, C., Urry, J., Eds.; Routledge: London, UK; New York, NY, USA, 1997; pp. 155-175.

3. Pap, N.; Kitanics, M.; Gyenizse, P.; Hancz, E.; Bognár, Z.; Tóth, T.; Hámori, Z. Finding the tomb of Suleiman the Magnificent in Szigetvár, Hungary: Historical, geophysical and archeological investigations. J. Geogr. Soc. Berl. 2015, 146, 289-303. [CrossRef]

4. Pap, N. The Pilgrimage Town (Türbe Kasabası) of Sultan Süleyman at Szigetvár. In The Battle for Central Europe: The Siege of Szigetvár and the Death of Süleyman the Magnificent and Nicholas Zrinyi (1566); Fodor, P., Ed.; Koninklijke Brill NV.: Budapest, Hungary; Leiden, The Netherlands; Boston, MA, USA, 2019; pp. 539-552. [CrossRef]

5. Partal, A.; Dunphy, K. Cultural impact assessment: A systematic literature review of current methods and practice around the world. Impact Assess 2016, 34, 1-13. [CrossRef]

6. De Medici, S.; De Toro, P.; Nocca, F. Cultural Heritage and Sustainable Development: Impact Assessment of Two Adaptive Reuse Projects in Siracusa, Sicily. Sustainability 2019, 12, 311. [CrossRef]

7. Evans, G. Tourism versus education-core functions of museums? In Tourism and Leisure-Culture, Heritage and Participation. Tourism and Leisure: Towards the Millennium; Leslie, D., Ed.; LSA: Brighton, UK, 1995; Volume 1, pp. 145-168.

8. Nocca, F. The Role of Cultural Heritage in Sustainable Development: Multidimensional Indicators as Decision-Making Tool. Sustainability 2017, 9, 1882. [CrossRef]

9. Timothy, D.J. The Political Nature of Cultural Heritage and Tourism; Timothy, D.J., Ed.; Routledge: Milton Park, Milton, UK, 2017. [CrossRef]

10. Pinto, J.K. Project Management: Achieving Competitive Advantage, 5th ed.; Pearson: London, UK, 2019.

11. Timothy, D.J. Cultural Heritage and Tourism: An Introduction; Channel View Publications: Bristol, UK, 2011.

12. Pap, N.; Jarjabka, Á.; Gálosi-Kovács, B.; Gonda, T.; Keresnyei, J.; Kovács, G.M.; Sipos, N.; Zagyi, N. Szigetvári Szulejmán Türbe Kulturális-Turisztikai Központ_Beruházási Projekt_Elözetes Megvalósíthatósági Tanulmány; Sulejmán Türbe: Pécs, Hungary, 2019.

13. Hall, C.M.; McArthur, S. Heritage Management in New Zealand and Australia: Visitor Management, Interpretation and Marketing; Oxford University Press: Oxford, UK, 1993.

14. Baxter, I.; Chippindale, C. From 'national disgrace' to flagship monument: Recent attempts to manage the future of Stonehenge. Conserv. Manag. Archaeol. Sites 2002, 5, 151-184. [CrossRef]

15. Gullino, P.; Beccaro, G.; Larcher, F. Assessing and Monitoring the Sustainability in Rural World Heritage Sites. Sustainability 2015, 7, 14186-14210. [CrossRef]

16. Pap, N.; Fodor, P. Szulejmán Szultán Szigetváron: A Szigetvári Kutatások 2013-2016 Között; Pannon Castrum: Pécs, Hungary, 2017.

17. 1427/2017. (VI. 29.) Korm. határozat a Szigetvár-turbéki Szőlőhegyen megkezdett feltárásról és az érintett ingatlanok állami tulajdonba kerülésével kapcsolatos intézkedésekről. Magyar Közlöny 2017, 10267. Available online: https://net.jogtar.hu/ jogszabaly?docid=A17H1427.KOR\&txtreferer=00000001.txt (accessed on 2 February 2021).

18. Simon, H.A. Models of Bounded Rationality. Volume 2: Behavioural Economics and Business Organization; MIT Press: Cambridge, MA, USA, 1982. 
19. Sipos, N.; Pap, N.; Keresnyei, J.; Jarjabka, Á. A Szigetvári Szulejmán Türbe Kulturális-Turisztikai Központ Projekt turisztikai megvalósíthatósági kockázatai. Tur. Vid. Tan. 2020, 5, 4-21. [CrossRef]

20. Gallagher, M.; Hares, T.I.M.; Spencer, J.; Bradshaw, C.; Webb, I.A.N. The Nominal Group Technique: A Research Tool for General Practice? Fam. Pract. 1993, 10, 76-81. [CrossRef]

21. Noonan, D.S.; Rizzo, I. Economics of cultural tourism: Issues and perspectives. J. Cult. Econ. 2017, 41, 95-107. [CrossRef]

22. Richards, G. The traditional quantitative approach. Surveying cultural tourists: Lessons from the ATLAS cultural tourism research project. In Cultural Tourism Research Methods; Richards, G., Munsters, W., Eds.; CABI: Oxfordshire, UK; Cambridge, MA, USA, 2010; pp. 13-32.

23. Cynarski, W.J. About qualitative research of cultural tourism. J. Martial Arts Anthropol. 2011, 11, $280-281$.

24. Richards, G. Production and consumption of European cultural tourism. Ann. Tour. Res. 1996, 23, 261-283. [CrossRef]

25. Nuryanti, W. Redefining cultural heritage through post-modern tourism. In Managing Cultural Resources for Tourism, Sunderland; Robinson, M., Evans, N., Callaghan, P., Eds.; Centre for Travel and Tourism: Sunderland, UK, 1996; pp. 335-348.

26. Richards, G. Cultural tourism: A review of recent research and trends. J. Hosp. Tour. Manag. 2018, 36, 12-21. [CrossRef]

27. García-Hernández, M.; De la Calle-Vaquero, M.; Yubero, C. Cultural Heritage and Urban Tourism: Historic City Centres under Pressure. Sustainability 2017, 9, 1346. [CrossRef]

28. Christou, E. Chapter 1-Heritage and cultural tourism: A marketing-focused approach. In International Cultural Tourism; Sigala, M., Leslie, D., Eds.; Butterworth-Heinemann: Oxford, UK, 2005; pp. 3-15. [CrossRef]

29. Steinecke, A. Kulturtourismus; Oldenbourg Wissenschaftsverlag: Munich, Germany, 2011. [CrossRef]

30. UNWTO. Siem Reap Declaration on Tourism and Culture-Building a New Partnership Model. UNWTO Declar. 2015, $24,1-11$. [CrossRef]

31. Richards, G. Creative tourism: Opportunities for smaller places? Tour. Man. Stud. 2019, 15, 7-10. [CrossRef]

32. Richards, G. Tourism Trends: The Convergence of Culture and Tourism. 2014. Available online: https://www.academia.edu/94 91857/Tourism_trends_The_convergence_of_culture_and_tourism (accessed on 3 March 2021).

33. Richards, G. General framework for a triangular partnership: Tourism, culture and communities. In Tourism and Culture Partnership in Peru-Models for Collaboration between Tourism, Culture and Community; UNWTO, Ed.; UNWTO: Madrid, Spain, 2016; pp. 17-28. [CrossRef]

34. Richards, G. Cultural contents utilization. In Tourism and Culture Partnership in Peru-Models for Collaboration between Tourism, Culture and Community; UNWTO, Ed.; UNWTO: Madrid, Spain, 2016; pp. 95-104. [CrossRef]

35. Amaral, R.; Serra, J. Back to the Same Place of Holidays. An Analysis of European Tourists' Preferences Towards Cultural Tourism. In Trends in Tourist Behavior. New Products and Experiences from Europe; Artal-Tur, A., Kozak, M., Kozak, N., Eds.; Springer International Publishing: Cham, Switzerland, 2019; pp. 195-208. [CrossRef]

36. Zhang, G.; Chen, X.; Law, R.; Zhang, M. Sustainability of Heritage Tourism: A Structural Perspective from Cultural Identity and Consumption Intention. Sustainability 2020, 12, 9199. [CrossRef]

37. Hargrove, C.M. Heritage Tourism. CRM Mag. 2002, 25, 10-11.

38. Cisneros-Martínez, J.D.; Fernández-Morales, A. Cultural tourism as tourist segment for reducing seasonality in a coastal area: The case study of Andalusia. Curr. Issues Tour. 2015, 18, 765-784. [CrossRef]

39. De Luca, G.; Dastgerdi, A.S.; Francini, C.; Liberatore, G. Sustainable Cultural Heritage Planning and Management of Overtourism in Art Cities: Lessons from Atlas World Heritage. Sustainability 2020, 12, 3929. [CrossRef]

40. Silberberg, T. Cultural tourism and business opportunities for museums and heritage sites. Tour. Manag. 1995, 16, 361-365. [CrossRef]

41. Stanzl, G. The ruins of the Abbey Disibodenberg near Mainz, Germany: Excavation, conservation and development of the site. Conserv. Manag. Archaeol. Sites 2013, 4, 21-32. [CrossRef]

42. Boyd, S. Cultural and Heritage Tourism in Canada: Opportunities, Principles and Challenges. Tour. Hosp. Res. 2016, 3, 211-233. [CrossRef]

43. Cynarski, W.; Obodyński, M. Cultural tourism in the light of Polish humanist theory of tourism. J. Martial. Arts Anthrop. 2010, $10,85-88$.

44. Csapó, J.; Törőcsik, M.; Ákos, N. Nemturizmus és életstílus összefüggések. Tur. Vid. Tan. 2019, 4, 4. [CrossRef]

45. Berki, M.; Gonda, T. A kulturális turizmus magyarországi városi helyszíneinek pozicionálása. Foldr. Ert. 2006, 55, 127-140.

46. Conti, A.L. Cultural heritage and tourism: Possibilities of a sustainable relationship. Past Future 2015, 10, 15-23. [CrossRef]

47. Kaposi, Z. Az épített örökség szerepe a turizmus fejlesztésében. A kastélyhasznosítás tapasztalatai somogy megye mintáján. Tur. Vid. Tan. 2018, 3, 18-27.

48. Thomas, G. The role of research and education in site management at the Lemba Experimental Village, Cyprus. Conserv. Manag. Archaeol. Sites 2013, 3, 109-123. [CrossRef]

49. Piskóti, I.; Bene, Z.; Marien, A.; Nagy, K.; Szakál, Z. Borút, borturizmus-integrált fejlesztési koncepció, módszertan és menedzsment-gyakorlat. Tur. Vid. Tan. 2019, 4, 4. [CrossRef]

50. Csapó, J.; Gerdesics, V.; Gonda, T.; Raffay, Z.; Törőcsik, M. Turizmus: A Magyar Lakosság Turizmussal Kapcsolatos Beállítódása Generációs Szemléletü Vizsgálattal—Országosan Reprezentatív Személyes $(n=2001)$ És Online $(n=1085)$ Megkérdezés, Fókuszcsoportos Viták Eredményei; PTE KTK: Pécs, Magyarország, 2018. 
51. Berti, E.; Penelope, D.; Mariotti, A. (Eds.) Cultural Routes Management from Theory to Pratice. Step by Step Guide to the Council of Europe Cultural Routes; Council of Europe Publishing: Strasbourg, France, 2015.

52. Rogerson, C.M. Tourism Routes as Vehicles for Local Economic Development in South Africa: The Example of the Magaliesberg Meander. Urban Forum 2007, 18, 49-68. [CrossRef]

53. Rogerson, C.M. Tourism and uneven local economic development: The experience of route tourism in South Africa. In Tourism and Development Issues in Contemporary South Africa; Rogerson, C.M., Visser, G., Eds.; Africa Institute of South Africa: Pretoria, South Africa, 2004; pp. 399-419.

54. Lourens, M. Route tourism: A roadmap for successful destinations and local economic development. Dev. S. Afr. 2007, 24, 475-490. [CrossRef]

55. Meyer, D.; Ashley, C.; Poultney, C. Developing Local Excursions for Tourists. Case Study Brief No.5. Pro-Poor Tourism Pilots Programme 2004. Available online: https://www.odi.org/sites/odi.org.uk/files/odi-assets/publications-opinion-files/3794.pdf (accessed on 4 February 2021).

56. Clarke, J. Effective Marketing for Rural Tourism. In Rural Tourism and Sustainable Business; Hall, D., Kirkpatrick, I., Mitchell, M., Eds.; Channel View Publications: Clevedon, UK, 2005; pp. 87-102. [CrossRef]

57. Briedenhann, J.; Wickens, E. Tourism routes as a tool for the economic development of rural areas-vibrant hope or impossible dream? Tour. Manag. 2004, 25, 71-79. [CrossRef]

58. Telfer, D.J. Strategic alliances along the Niagara Wine Route. Tour. Manag. 2001, 22, 21-30. [CrossRef]

59. Rogerson, C.M.; Rogerson, J.M. Craft routes for developing craft business in South Africa: Is it a good practice or limited policy option? Afr. J. Bus. Manag. 2011, 5, 11736-11748. [CrossRef]

60. Majdoub, W. Analyzing cultural routes from a multidimensional perspective. J. Tour. Cult. Ter. Dev. 2010, 1, 29-37. [CrossRef]

61. Fladmark, J.M.; Habgood, J. Cultural Tourism: Papers Presented at the Robert Gordon University Heritage Convention 1994; Fladmark, J.M., Ed.; Donhead: London, UK, 1994; p. 413.

62. Loulanski, T.; Loulanski, V. The sustainable integration of cultural heritage and tourism: A meta-study. J. Sustain. Tour. 2011, 19, 837-862. [CrossRef]

63. Coccossis, H. Cultural heritage, local resources and sustainable tourism. Int. J. Serv. Technol. Manag. 2008, 10, 8-14. [CrossRef]

64. Jovicic, D. Cultural tourism in the context of relations between mass and alternative tourism. Curr. Issues Tour. 2016, 19, 605-612. [CrossRef]

65. Jarjabka, Á.; Sipos, N.; Dobos, O.; Kremmer, L.; Ásványi, Z.; Vajkai, A.; Merza, P.; Hornyák, M. Projektmenedzsment Ismeretek. [elektronikus dok.], 3rd ed.; PTE KTK: Pécs, Hungary, 2020.

66. Szabó, L. Projekt Menedzsment; Pearson Education Limited: London, UK, 2012.

67. Burke, R. Project Management: Planning and Control Techniques, 3rd ed.; J. Wiley: New Jersey, USA, 2002.

68. Uğur, N.G.; Akbıyık, A. Impacts of COVID-19 on global tourism industry: A cross-regional comparison. Tour. Manag. Perspect. 2020, 36, 100744. [CrossRef]

69. Persson-Fischer, U.; Liu, S. The Impact of a Global Crisis on Areas and Topics of Tourism Research. Sustainability 2021, 13, 906. [CrossRef]

70. Shirvani Dastgerdi, A.; De Luca, G.; Francini, C. Reforming Housing Policies for the Sustainability of Historic Cities in the Post-COVID Time: Insights from the Atlas World Heritage. Sustainability 2020, 13, 174. [CrossRef]

71. McKibbin, W.; Fernando, R. The Global Macroeconomic Impacts of COVID-19: Seven Scenarios. Asian. Econ. Pap. 2020, 20, 1-30. [CrossRef]

72. Palmi, P.; Esposito, M.; Prete, M.I. Change in Perspectives in Cultural Tourism: A Sustainable Managerial Model for Cultural Thematic Routes Creating Territorial Value. In Cultural Initiatives for Sustainable Development; Demartini, P., Marchegiani, L., Marchiori, M., Schiuma, G., Eds.; Springer: Berlin/Heidelberg, Germany, 2021; pp. 199-223. [CrossRef]

73. Menoni, S.; Molinari, D.; Parker, D.; Ballio, F.; Tapsell, S. Assessing multifaceted vulnerability and resilience in order to design risk-mitigation strategies. Nat. Hazards 2012, 64, 2057-2082. [CrossRef]

74. Dale, C.; Robinson, N. Dark tourism. In Research Themes for Tourism; Robinson, P., Heitmann, S., Dieke, P., Eds.; CABI: Wallingford, UK, 2010; pp. 205-217. [CrossRef]

75. Throsby, D. Sustainability and culture some theoretical issues. Int. J. Cult. Policy 1997, 4, 7-19. [CrossRef]

76. Sunindijo, R.Y.; Hadikusumo, B.H.; Ogunlana, S. Emotional Intelligence and Leadership Styles in Construction Project Management. J. Manage. Eng. 2007, 23, 166-170. [CrossRef]

77. Vetrova, E.A.; Kabanova, E.E.; Nakhratova, E.E.; Baynova, M.S.; Evstratova, T.A. Project Management in the Sphere of Tourism (Using the Example of Taganrog). Acad. Strateg. Manag. J. 2018, 17, 1-9.

78. Szávai, P. Az örökség interpretálásának új útjai: A Mohácsi Nemzeti Emlékhely. ME. DOK 2016, 11, 31-42.

79. Tóth, É. Vérbetúkkel íratott-1526. TOPOS 2014, 1, 115-158. 